ARTICLE

https://doi.org/10.1038/s41467-019-11407-2

\title{
Construction of stabilized bulk-nano interfaces for highly promoted inverse $\mathrm{CeO}_{2} / \mathrm{Cu}$ catalyst
}

\author{
Han Yan ${ }^{1}$, Chun Yang ${ }^{1}$, Wei-Peng Shao ${ }^{1}$, Li-Hua Cai ${ }^{1}$, Wei-Wei Wang ${ }^{1}$, Zhao $\operatorname{Jin}^{1} \&$ Chun-Jiang Jia (1) ${ }^{1}$
}

As the water-gas shift (WGS) reaction serves as a crucial industrial process, strategies for developing robust WGS catalysts are highly desiderated. Here we report the construction of stabilized bulk-nano interfaces to fabricate highly efficient copper-ceria catalyst for the WGS reaction. With an in-situ structural transformation, small $\mathrm{CeO}_{2}$ nanoparticles $(2-3 \mathrm{~nm})$ are stabilized on bulk $\mathrm{Cu}$ to form abundant $\mathrm{CeO}_{2}-\mathrm{Cu}$ interfaces, which maintain well-dispersed under reaction conditions. This inverse $\mathrm{CeO}_{2} / \mathrm{Cu}$ catalyst shows excellent WGS performances, of which the activity is 5 times higher than other reported Cu catalysts. Long-term stability is also very solid under harsh conditions. Mechanistic study illustrates that for the inverse $\mathrm{CeO}_{2} / \mathrm{Cu}$ catalyst, superb capability of $\mathrm{H}_{2} \mathrm{O}$ dissociation and $\mathrm{CO}$ oxidation facilitates WGS process via the combination of associative and redox mechanisms. This work paves a way to fabricate robust catalysts by combining the advantages of bulk and nano-sized catalysts. Catalysts with such inverse configurations show great potential in practical WGS applications.

\footnotetext{
${ }^{1}$ Key Laboratory for Colloid and Interface Chemistry, Key Laboratory of Special Aggregated Materials, School of Chemistry and Chemical Engineering, Shandong University, 250100 Jinan, China. Correspondence and requests for materials should be addressed to C.-J.J. (email: jiacj@sdu.edu.cn)
} 
$\mathrm{B}$ ulk catalysts with stable structure have been applied to many industrial procedures, such as fused Fe for ammonia synthesis ${ }^{1}$ and $\mathrm{Cu}-\mathrm{Zn}-\mathrm{Al}$ for water-gas shift (WGS) reaction $^{2}$. In recent years, the introduction of nanotechnology has brought valuable insights into heterogeneous catalysis. Remarkable catalytic performances in many reactions have been discovered for supported nanoparticles, clusters, and single atoms $s^{3-7}$, of which defects and vacancies on the oxide supports are often considered as important anchoring sites. One major shortcoming of these supported catalysts is the vulnerability against sintering ${ }^{8-10}$. The highly dispersed active sites tend to aggregate and deactivate under reaction conditions. Thus, combining the advantages of bulk and nano-sized catalysts is of great significance, though it seems tough, since the bulk structure contradicts the high dispersion.

WGS $\left(\mathrm{CO}+\mathrm{H}_{2} \mathrm{O}=\mathrm{CO}_{2}+\mathrm{H}_{2}\right)$ reaction is a crucial process in $\mathrm{H}_{2}$ production industry ${ }^{11}$, to which $\mathrm{Cu}$-based catalysts have been applied for decades ${ }^{12-14}$. $\mathrm{Cu}-\mathrm{CeO}_{2}$ has been considered as promising alternative to $\mathrm{Cu}-\mathrm{Zn}-\mathrm{Al}$ catalyst, while it still suffers from low activity caused by $\mathrm{Cu}$ sintering ${ }^{15-17}$. It has been known that the metal-oxide interface plays a critical role in catalyzing WGS reaction, of which the key is the adsorption and activation of reactants ${ }^{18-20}$. To deeply understand the interface effect, catalysts with inverse configuration have been designed ${ }^{21-23}$. Different to commonly supported catalysts, for which active metals are loaded onto the oxide supports, active metals serve as the support for oxides nanoparticles in inverse catalyst ${ }^{24-27}$. Model inverse $\mathrm{CeO}_{x} /$ $\mathrm{Cu}(111)$ has shown superior WGS activity to normal $\mathrm{Cu}$ / $\mathrm{CeO}_{2}(111)$, owing to enhanced reducibility of $\mathrm{CeO}_{2}{ }^{28}$. Meanwhile, the $\mathrm{CeO}_{2}-\mathrm{Cu}$ interface could be highly stable, since bulk $\mathrm{Cu}$ has grown well and $\mathrm{CeO}_{2}$ nanoparticles are anti-sintering under WGS conditions, which is very beneficial to the catalyst stability. Thus, prominent activity and stability promotion of $\mathrm{Cu}-\mathrm{CeO}_{2}$ catalyst is expected by applying inverse configuration. However, the assumed high WGS activity has never been found on real $\mathrm{CeO}_{2} / \mathrm{Cu}$ catalyst, due to severe separation of bulk $\mathrm{Cu}$ and $\mathrm{CeO}_{2}$ nanoparticles ${ }^{29}$. Therefore, strategies to fabricate inverse $\mathrm{CeO}_{2} / \mathrm{Cu}$ catalyst with sufficient bulk-nano interfaces are in great need.

Herein, we have constructed stabilized bulk-nano interfaces to fabricate inverse $\mathrm{CeO}_{2} / \mathrm{Cu}$ catalyst, through which the advantages of bulk and nano-sized catalysts are perfectly combined. With an in situ structural transformation, $\mathrm{CeO}_{2}$ nanoparticles $(2-3 \mathrm{~nm})$ are dispersed on bulk $\mathrm{Cu}$, forming sufficient $\mathrm{CeO}_{2}-\mathrm{Cu}$ interfaces with great stability. Enrichment of stable bulk-nano interfaces results in great promotion of WGS activity and stability. The inverse $\mathrm{CeO}_{2} / \mathrm{Cu}$ catalyst achieves a remarkable WGS reaction rate of $47.3 \mu \mathrm{mol} \mathrm{g}^{-1} \mathrm{~s}^{-1}\left(300^{\circ} \mathrm{C}\right)$, which is at least five times of that for other $\mathrm{Cu}$ catalysts. Mechanistic study demonstrates the $\mathrm{CeO}_{2} / \mathrm{Cu}$ catalyst possesses superb capability of $\mathrm{H}_{2} \mathrm{O}$ dissociation and $\mathrm{CO}$ oxidation, which facilitates WGS reaction via the combination of associative and redox mechanism. Development of such inverse catalyst is very likely to make huge breakthrough in the exploration of other robust catalysts.

\section{Results}

Catalytic performances of the inverse $\mathrm{CeO}_{2} / \mathrm{Cu}$ catalyst. A series of catalysts with different $\mathrm{Cu} / \mathrm{Ce}$ ratio was prepared via an aerosol-spray method ${ }^{30-32}$. As shown in Supplementary Fig. 1a and $c$, the inverse $\mathrm{CeO}_{2} / \mathrm{Cu}$ catalyst with $\mathrm{Cu} / \mathrm{Ce}$ ratio of 9:1 showed the highest and repeatable WGS activity. Increased or decreased proportion of $\mathrm{Cu}$ led to lower $\mathrm{CO}$ conversion (Supplementary Fig. 1b). The physical and chemical properties of the catalysts are listed in Supplementary Table 1 . Fresh $\mathrm{CeO}_{2} / \mathrm{Cu}$ catalyst contained $61.5 \mathrm{wt} \%$ of $\mathrm{Cu}$, and the $\mathrm{Cu}$ content elevated to
$82.9 \mathrm{wt} \%$ after WGS reaction, due to the reduction of $\mathrm{CuO}$ to $\mathrm{Cu}$. The $17.1 \mathrm{wt} \% \mathrm{CeO}_{2}$ loading corresponded well to the finding of Rodriguez et al. ${ }^{24}$, illustrating the optimal $\mathrm{CeO}_{2}$ coverage on $\mathrm{Cu}$ surface was around $20 \%$. For supported $\mathrm{Cu} / \mathrm{CeO}_{2}$ catalyst, $10 \mathrm{wt} \%$ of $\mathrm{Cu}$ has often been applied to obtain an effective catalyst ${ }^{33-35}$. Therefore, normal $\mathrm{Cu} / \mathrm{CeO}_{2}$ catalyst, with $10.7 \mathrm{wt} \%$ of $\mathrm{Cu}$, was chosen for comparison.

In Table 1, the two fresh catalysts exhibited similar specific BET surface areas $\left(S_{\mathrm{BET}}, 46-48 \mathrm{~m}^{2} \mathrm{~g}^{-1}\right)$. After catalysis, the $S_{\mathrm{BET}}$ of $\mathrm{CeO}_{2} / \mathrm{Cu}$ catalyst $\left(16.2 \mathrm{~m}^{2} \mathrm{~g}^{-1}\right)$ apparently decreased, while that of $\mathrm{Cu} / \mathrm{CeO}_{2}$ catalyst $\left(42.8 \mathrm{~m}^{2} \mathrm{~g}^{-1}\right)$ was well preserved. $\mathrm{Cu}$ surface area $\left(S_{\mathrm{Cu}}\right)$ was also calculated for both catalysts (see Supplementary Methods for detail). The $S_{\mathrm{Cu}}$ of $\mathrm{Cu} / \mathrm{CeO}_{2}\left(71.7 \mathrm{~m}^{2} \mathrm{~g}^{-1}\right)$ was also higher than that of $\mathrm{CeO}_{2} / \mathrm{Cu}\left(50.7 \mathrm{~m}^{2} \mathrm{~g}^{-1}\right)$. However, the inverse $\mathrm{CeO}_{2} / \mathrm{Cu}$ catalyst exhibited much higher WGS conversion than that of $\mathrm{Cu} / \mathrm{CeO}_{2}$ catalyst (Fig. 1a). Within the tested temperature range, the reaction rate $(r)$ of $\mathrm{CeO}_{2} / \mathrm{Cu}$ measured under kinetics conditions was 4-5 times higher than that of $\mathrm{Cu} / \mathrm{CeO}_{2}$ catalyst. Under the industrial WGS atmosphere, as illustrated in Fig. 1b, the activity of inverse $\mathrm{CeO}_{2} / \mathrm{Cu}$ catalyst was very close to that of commercial $\mathrm{Cu}-\mathrm{Zn}-\mathrm{Al}$, approaching the equilibrium in harsh reaction conditions. To further demonstrate the promotion of WGS activity, $r$ values at $300{ }^{\circ} \mathrm{C}$ for different catalysts were illustrated in Fig. 1c. Normal $\mathrm{Cu} / \mathrm{CeO}_{2}$ gave $r$ of $10.2 \mu \mathrm{mol} \mathrm{g}^{-1} \mathrm{~s}^{-1}$, slightly higher than that of reported $\mathrm{Cu}-\mathrm{Ce}(\mathrm{La}) \mathrm{O}_{x}\left(9.0 \mu \mathrm{mol} \mathrm{g}^{-1} \mathrm{~s}^{-1}\right)^{15}$. The similar $r$ values here reflected the general WGS activity of supported $\mathrm{Cu} / \mathrm{CeO}_{2}$ catalysts. Meanwhile, the inverse $\mathrm{CeO}_{2} / \mathrm{Cu}$ gave a very high $r$ value of $47.3 \mu \mathrm{mol} \mathrm{g}^{-1} \mathrm{~s}^{-1}$, which was five times that of normal $\mathrm{Cu} / \mathrm{CeO}_{2}$ catalyst. Compared to former inverse $\mathrm{CeO}_{x} / \mathrm{Cu}$ catalyst $\left(9.8 \mu \mathrm{molg}^{-1} \mathrm{~s}^{-1}\right)^{29}$, the $r$ of inverse $\mathrm{CeO}_{2} / \mathrm{Cu}$ was also much higher. The activities of some efficient WGS catalysts are listed in Supplementary Table 2. The inverse $\mathrm{CeO}_{x} / \mathrm{Cu}$ catalyst exhibited the highest $r$ among the Cu-based catalysts, and its activity was even close to supported $\mathrm{Pt}$ catalysts ${ }^{36,37}$. Thus, we believe that the inverse $\mathrm{CeO}_{2} / \mathrm{Cu}$ catalyst with tremendous WGS activity has been successively developed. Arrhenius plots for the catalysts were constructed by using the $\ln$ of $r$ (Supplementary Fig. 2). In the repeated experiments, the WGS on inverse $\mathrm{CeO}_{2} / \mathrm{Cu}$ gave an apparent energy $\left(E_{\mathrm{a}}\right)$ of ca. $37 \mathrm{~kJ} \mathrm{~mol}^{-1}$, which was a little lower than that (ca. $40 \mathrm{~kJ} \mathrm{~mol}^{-1}$ ) found on normal $\mathrm{Cu} / \mathrm{CeO}_{2}$.

For WGS catalysts, sintering is often considered as the main reason for deactivation ${ }^{8-10,38}$. The well-dispersed active species may aggregate and deactivate rapidly under reaction conditions. Figure $1 \mathrm{~d}$ present the results of time-on-stream stability tests. Normal $\mathrm{Cu} / \mathrm{CeO}_{2}$ gave very low $r\left(3 \mu \mathrm{mol} \mathrm{g}^{-1} \mathrm{~s}^{-1}\right)$, while the inverse $\mathrm{CeO}_{2} / \mathrm{Cu}$ exhibited surprisingly high stability. With the temperature of $250{ }^{\circ} \mathrm{C}$ and very high space velocity of 600,000 $\mathrm{cm}^{3} \mathrm{~g}^{-1} \mathrm{~h}^{-1}$, the WGS $r$ of the inverse $\mathrm{CeO}_{2} / \mathrm{Cu}$ maintained at $17 \mu \mathrm{mol} \mathrm{g}^{-1} \mathrm{~s}^{-1}$, showing negligible decrease in the test up to 50 h. The long-term stability of commercial $\mathrm{Cu}-\mathrm{Zn}-\mathrm{Al}$ was measured as well. The initial $r$ of $\mathrm{Cu}-\mathrm{Zn}-\mathrm{Al}$ was slightly higher than that of inverse $\mathrm{CeO}_{2} / \mathrm{Cu}$. After $50 \mathrm{~h}$ test, the $r$ dropped from 19.5 to $14.8 \mu \mathrm{mol} \mathrm{g}^{-1} \mathrm{~s}^{-1}$. Thus, the $\mathrm{CeO}_{2} / \mathrm{Cu}$ catalyst gave very solid performance in the time-on-stream test, which showed superior stability under very high space velocity $\left(600,000 \mathrm{~cm}^{3} \mathrm{~g}^{-1} \mathrm{~h}^{-1}\right)$.

Construction of bulk-nano interfaces. The catalytic performances were largely determined by the structure of the catalysts. $\mathrm{CeO}_{2}$ has been well known as suitable support for $\mathrm{Cu}$ catalysts, since the strong interaction between $\mathrm{CuO}$ and $\mathrm{CeO}_{2}$ could achieve homogeneous $\mathrm{Cu}$ dispersion ${ }^{39-41}$. For the fresh $\mathrm{CeO}_{2} / \mathrm{Cu}$ catalyst, such interaction could be confirmed by temperatureprogrammed reduction by $\mathrm{H}_{2}\left(\mathrm{H}_{2}-\mathrm{TPR}\right)$, with the fact that reducibility for $\mathrm{CuO}$ was enhanced after $\mathrm{CeO}_{2}$ addition 


\section{Table 1 Physicochemical properties of fresh and used catalysts}

\begin{tabular}{|c|c|c|c|c|c|c|c|c|c|c|c|}
\hline \multirow{2}{*}{$\frac{\text { Catalyst }}{\mathrm{CeO}_{2} / \mathrm{Cu}}$} & \multicolumn{2}{|c|}{ Cu (wt\%) } & \multicolumn{2}{|c|}{$d_{\mathrm{CeO} 2}(\mathrm{~nm})^{\mathrm{b}}$} & \multicolumn{2}{|c|}{$d_{C_{u}}(n m)^{b}$} & \multicolumn{2}{|c|}{$S_{\text {BET }}\left(m^{2} g^{-1}\right)$} & \multirow{2}{*}{$\frac{\mathbf{S}_{\mathbf{C u}}\left(\mathbf{m}^{\mathbf{2}} \mathbf{g}^{-\mathbf{1}}\right)}{50.7}$} & \multirow{2}{*}{$\frac{\text { TOF }\left(\mathbf{s}^{-\mathbf{1}} \mathbf{)} \mathbf{c}\right.}{0.058}$} & \multirow{2}{*}{$\frac{\text { Interface sites }}{4.9 \times 10^{20}}$} \\
\hline & $61.5^{d}$ & $82.9^{e}$ & $2.6^{d}$ & $2.7^{\mathrm{e}}$ & $8.0^{d}$ & $101.2^{\mathrm{e}}$ & $47.7^{d}$ & $16.2^{\mathrm{e}}$ & & & \\
\hline $\mathrm{Cu} / \mathrm{CeO}_{2}$ & 10.7 & 13.4 & 3.6 & 4.7 & - & - & 46.2 & 42.8 & 71.7 & 0.056 & $1.1 \times 10^{20}$ \\
\hline
\end{tabular}

Weight ratio of fresh catalysts determined by EDS

b $\mathrm{CuO}$ for fresh samples, Cu for used samples. Determined by the XRD patterns and Scherrer formula

cSee detailed calculation process in Supplementary Methods

${ }^{\mathrm{d} D a t a}$ acquired from fresh catalysts

eData acquired from used catalysts

a

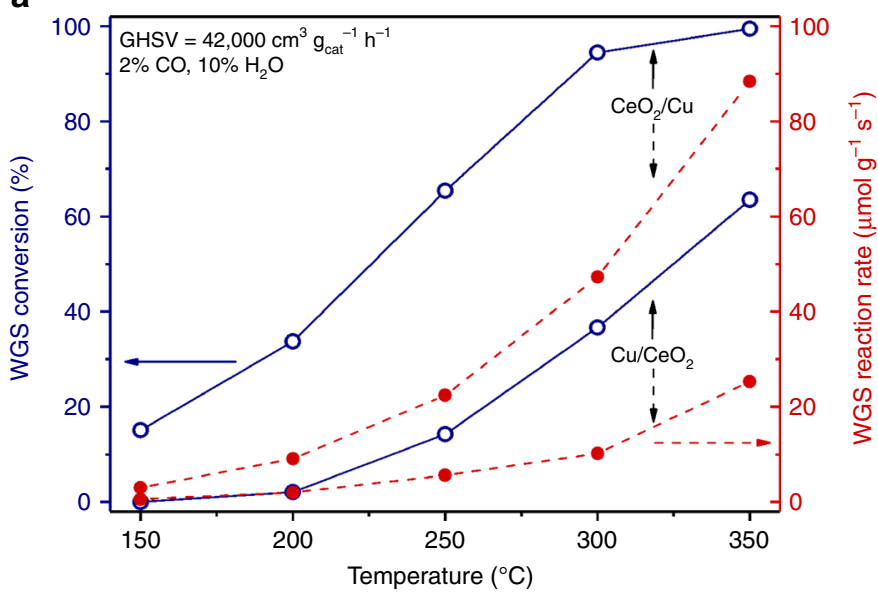

C

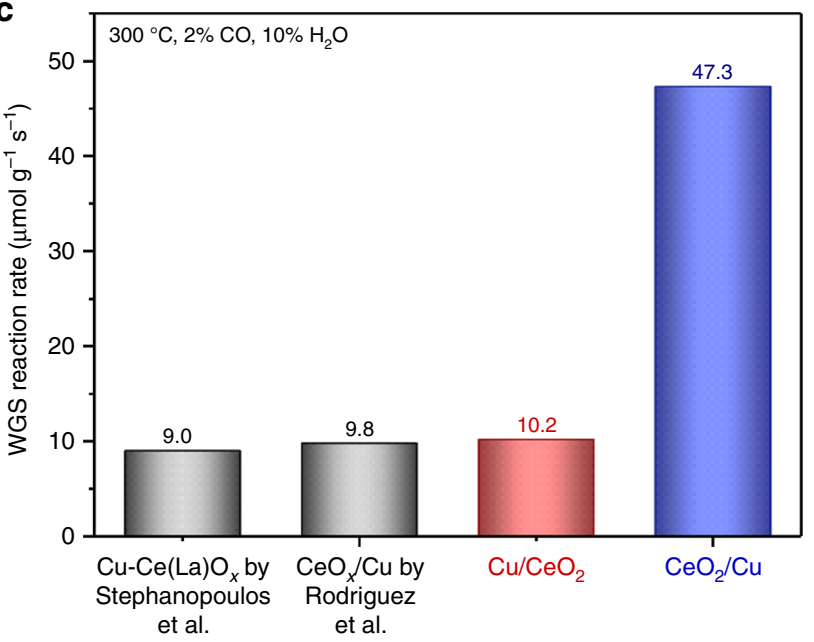

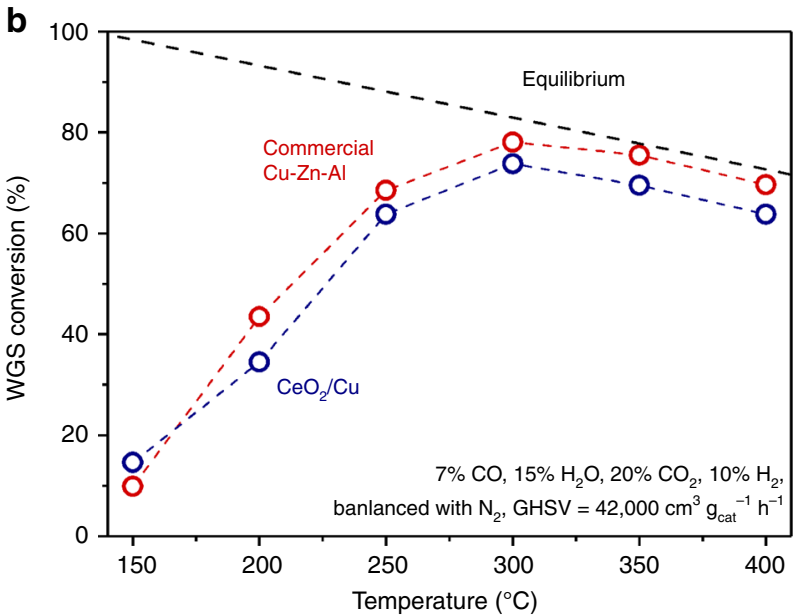

d

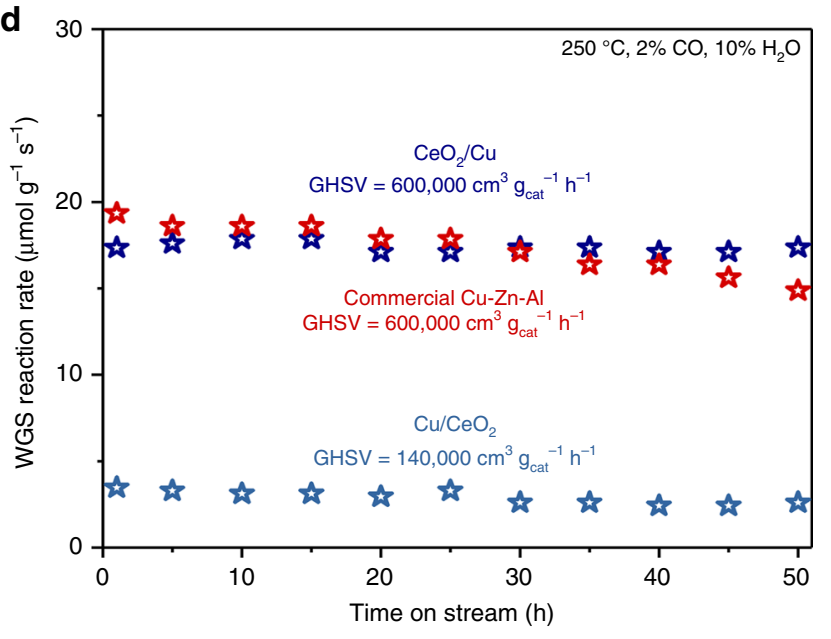

Fig. 1 Catalytic performances of the inverse $\mathrm{CeO}_{2} / \mathrm{Cu}$ catalyst. a Water-gas shift (WGS) activities of the inverse $\mathrm{CeO} / 2 / \mathrm{Cu}$ and normal $\mathrm{Cu} / \mathrm{CeO} 2$ catalysts. b WGS activities of the inverse $\mathrm{CeO}_{2} / \mathrm{Cu}$ catalyst and commercial $\mathrm{Cu}-\mathrm{Zn}-\mathrm{Al}$ under industrial atmosphere. c Comparison of WGS reaction rates for different catalysts at $300^{\circ} \mathrm{C}$. d Time-on-stream tests of the inverse $\mathrm{CeO}_{2} / \mathrm{Cu}$, normal $\mathrm{Cu} / \mathrm{CeO}_{2}$ catalysts, and commercial $\mathrm{Cu}-\mathrm{Zn}-\mathrm{Al}$

(Supplementary Fig. 3). Moreover, the strong $\mathrm{CuO}-\mathrm{CeO}_{2}$ interaction was convinced by the X-ray photoelectron spectroscopy (XPS) (Supplementary Fig. 4a) and ultraviolet-visible spectroscopy (UV-vis) analysis (Supplementary Fig. 5a), showing peak shifting and broadening with increased $\mathrm{CeO}_{2}$ content. The strong $\mathrm{CuO}-\mathrm{CeO}_{2}$ interaction enhanced the redox properties of the catalysts, and improved the dispersion of both $\mathrm{Cu}$ and $\mathrm{CeO}_{2}$. Raman spectra of the catalysts depicted in Supplementary Fig. 5b exhibited a tiny peak of Raman mode $A_{\mathrm{g}}{ }^{42,43}$, which belonged to cupric oxide. Thus, it seemed difficult to tell whether $\mathrm{CeO}_{2}$ was doped into $\mathrm{CuO}$ lattice.

The structural and chemical information of inverse $\mathrm{CeO}_{2} / \mathrm{Cu}$ catalyst is given in Fig. 2. The transmission electron microscopy
(TEM) image (Fig. 2a) of fresh inverse $\mathrm{CeO}_{2} / \mathrm{Cu}$ catalysts present morphology of microspheres with diameters ranging from 200 to $500 \mathrm{~nm}$. These microspheres were stacked of $\mathrm{CuO}$ and $\mathrm{CeO}_{2}$ nanoparticles. After WGS reaction, the microspheres became condensed and formed bulk particles (Fig. 2b). Catalysts with other $\mathrm{Cu}-\mathrm{Ce}$ ratios exhibited similar size and morphology (Supplementary Fig. 6). Powder X-ray diffraction (XRD) results (Supplementary Fig. 7) showed that monoclinic $\mathrm{CuO}$ and fluorite $\mathrm{CeO}_{2}$ served as dominate phase for the fresh catalyst. In Fig. $2 c$, the XRD pattern of $\mathrm{Cu} / \mathrm{CeO}_{2}$ had no observable change after WGS test, indicating the $\mathrm{Cu}$-species remained well-dispersed. This observation correlated well with the stable nature of $\mathrm{Cu} / \mathrm{CeO}_{2}$ (Fig. 1d). For inverse $\mathrm{CeO}_{2} / \mathrm{Cu}$ 
a

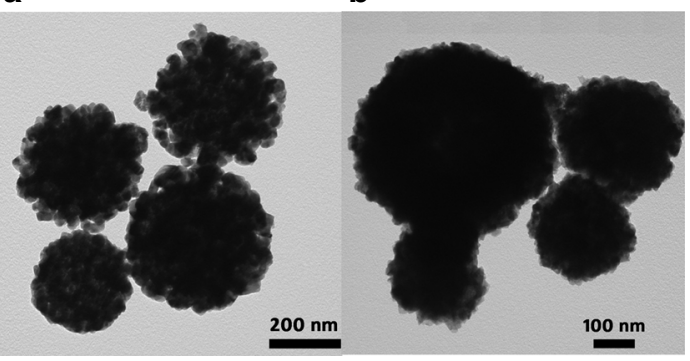

e $\quad \mathbf{f}$

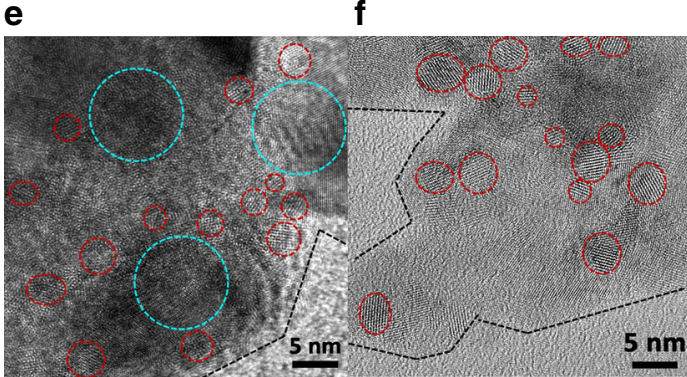

g

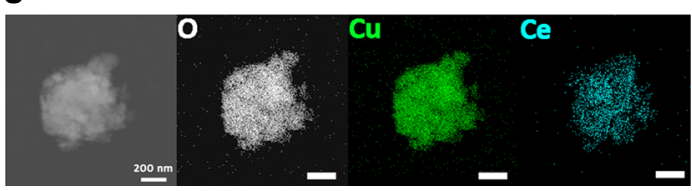

C

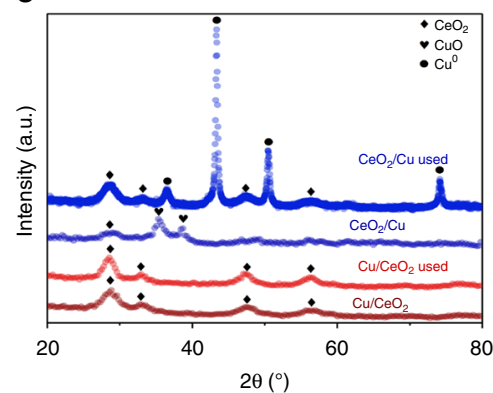

h

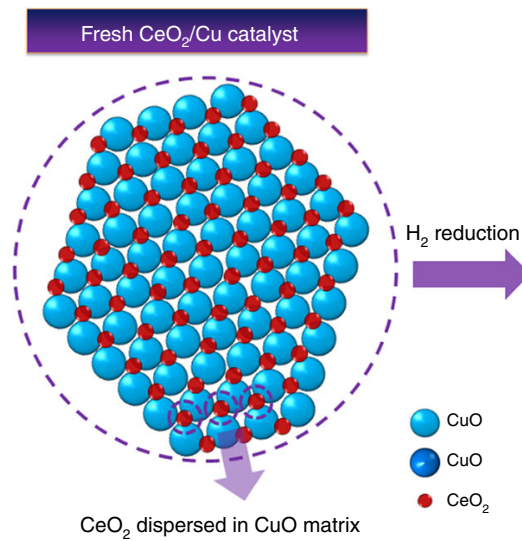

$\mathrm{CeO}_{2}$ dispersed in $\mathrm{CuO}$ matrix d

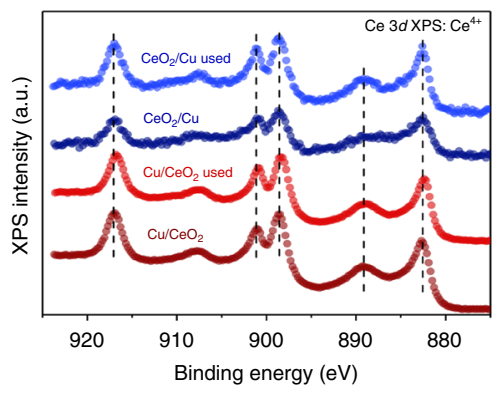

Used $\mathrm{CeO}_{2} / \mathrm{Cu}$ catalyst

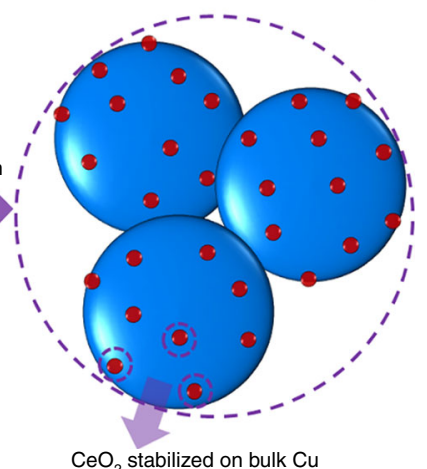

Fig. 2 Structure evolution of inverse $\mathrm{CeO}_{2} / \mathrm{Cu}$ catalyst during WGS reaction. $\mathbf{a}, \mathbf{b}$ Transmission electron microscope (TEM) images of $\mathbf{a}$ fresh and $\mathbf{b}$ used inverse $\mathrm{CeO}_{2} / \mathrm{Cu}$ catalysts. $\mathbf{c}$ X-ray diffraction (XRD) patterns of the fresh and used catalysts. $\mathbf{d}$ Ce $3 d$ X-ray photoelectron spectroscopy (XPS) results of the fresh and used catalysts. e, $\mathbf{f}$ High-resolution TEM (HR-TEM) images of fresh e and used $\mathbf{f}$ inverse $\mathrm{CeO}_{2} / \mathrm{Cu}_{\text {catalyst, red circles reflect to } \mathrm{CeO}}$, blue circles reflect to $\mathrm{CuO}$. g Scanning transmission electron microscope (STEM) image and element mapping results of used inverse $\mathrm{CeO}_{2} / \mathrm{Cu}_{\mathrm{c}} \mathrm{catalyst}$, the inset bar: $200 \mathrm{~nm}$. $\mathbf{h}$ Scheme of structural evolution for inverse $\mathrm{CeO}_{2} / \mathrm{Cu}$ catalyst during WGS reaction, $\mathrm{CeO}_{2}$ nanoparticles are well stabilized despite $\mathrm{Cu}$ sintering

catalyst, sharp metallic $\mathrm{Cu}$ peaks emerged after WGS test, and the crystalline size of $\mathrm{Cu}$ reached $101.2 \mathrm{~nm}$ (Table 1). The XRD results were consistent with the trend of dispersity for $\mathrm{Cu}$ (Supplementary Table 1), though $\mathrm{CeO}_{2}$ has been found to participate in $\mathrm{N}_{2} \mathrm{O}$ chemisorption, causing higher measured dispersion ${ }^{44}$. The XRD data demonstrated that the $\mathrm{CeO}_{2} / \mathrm{Cu}$ catalyst underwent severe sintering and bulk $\mathrm{Cu}$ was formed during WGS reaction. However, even though formation of bulk $\mathrm{Cu}$ was observed, the WGS activity and long-term stability of inverse $\mathrm{CeO}_{2} / \mathrm{Cu}$ were surprisingly excellent (Fig. 1). This finding was contrary to former knowledge that WGS was favored with smaller $\mathrm{Cu}$-species ${ }^{38,45}$. The unusual phenomenon could be well explained by the fact that WGS reaction occurred at $\mathrm{CeO}_{2}-\mathrm{Cu}$ interfaces of inverse $\mathrm{CeO}_{2} / \mathrm{Cu}$. As the bulk $\mathrm{Cu}$ was present, sufficient interfaces could be created if $\mathrm{CeO}_{2}$ was well dispersed. Small $\mathrm{CeO}_{2}$ nanoparticles supported on $\mathrm{CuO}$ were confirmed by high-resolution TEM (HR-TEM) images in Fig. 2e and Supplementary Fig. 8. After WGS reaction, small-sized $\mathrm{CeO}_{2}(2-3 \mathrm{~nm})$ was still well-dispersed on bulk $\mathrm{Cu}$ (Fig. $2 \mathrm{f}$ and Supplementary Fig. 8). The element mapping results (Fig. 2g) further demonstrated the high dispersion of $\mathrm{CeO}_{2}$, with $\mathrm{Ce}$ signal appearing uniformly on the surface of used $\mathrm{CeO}_{2} / \mathrm{Cu}$ catalyst. XPS profiles of Ce $3 d$ were recorded in Fig. 2d. For both inverse and normal catalysts, $\mathrm{Ce}^{4+}$ present as the dominating chemical state before and after WGS reaction. The other prepared $\mathrm{Cu}-\mathrm{CeO}_{2}$ catalysts also exhibited only $\mathrm{Ce}^{4+}$ (Supplementary Fig. 4b). Combining with the fact that no shift for the $\mathrm{CeO}_{2} \mathrm{XRD}$ peaks were observed (Fig. 2c), we believed that the $\mathrm{CeO}_{2}$ nanoparticles were supported on $\mathrm{CuO}$, rather than incorporated into the $\mathrm{CuO}$ lattice. Therefore, enriched $\mathrm{CeO}_{2}-\mathrm{Cu}$ interfaces were present in the inverse $\mathrm{CeO}_{2} / \mathrm{Cu}$ catalyst.

The structural evolution of the inverse catalyst is depicted in Fig. 2h. With the strong interaction, $\mathrm{CeO}_{2}$ nanoparticles were well dispersed in $\mathrm{CuO}$ matrix of the fresh sample. After $\mathrm{H}_{2}$ reduction, $\mathrm{CuO}$ was reduced and sintered to form bulk $\mathrm{Cu}$. Meanwhile, the $\mathrm{CeO}_{2}$ nanoparticles showed outstanding stability, holding high dispersion under WGS conditions. The aerosol-spray method enabled the inverse $\mathrm{CeO}_{2} / \mathrm{Cu}$ catalyst to give homogeneous $\mathrm{Cu}-\mathrm{CeO}_{2}$ dispersion, which induced an in situ structural transformation, resulting in $\mathrm{CeO}_{2}$ nanoparticles $(2-3 \mathrm{~nm})$ stabilized on bulk $\mathrm{Cu}$. The construction of bulk-nano interfaces brought stable structure of bulk materials and high dispersion of nano-sized catalysts. Tremendous promotion in WGS activity was thus achieved via creation of such bulk-nano interfaces, which was no longer at the risk of sintering deactivation.

Simulation of sintering via in situ XRD. In order to better simulate the sintering phenomenon during catalysis, in situ XRD measurements under $5 \% \mathrm{H}_{2} / \mathrm{Ar}$ were performed towards the inverse and normal catalysts. As shown in Fig. 3a, the peaks for metallic $\mathrm{Cu}$ of inverse $\mathrm{CeO}_{2} / \mathrm{Cu}$ catalyst emerged at $150{ }^{\circ} \mathrm{C}$ and sharpened, indicating rapid sintering of $\mathrm{Cu}$. Amplified $\mathrm{Cu}$ region in Fig. 3d illustrates that bulk $\mathrm{Cu}$ formed below $200{ }^{\circ} \mathrm{C}$. For normal $\mathrm{Cu} / \mathrm{CeO}_{2}$ catalyst (Fig. 3b), no obvious $\mathrm{Cu}$ peaks could be observed. Amplified $\mathrm{Cu}$ region in Fig. 3e displayed a tiny $\mathrm{Cu}$ peak centered at $43^{\circ}$. The $\mathrm{Cu}$ peak was absent for used $\mathrm{Cu} / \mathrm{CeO}_{2}$ 
a
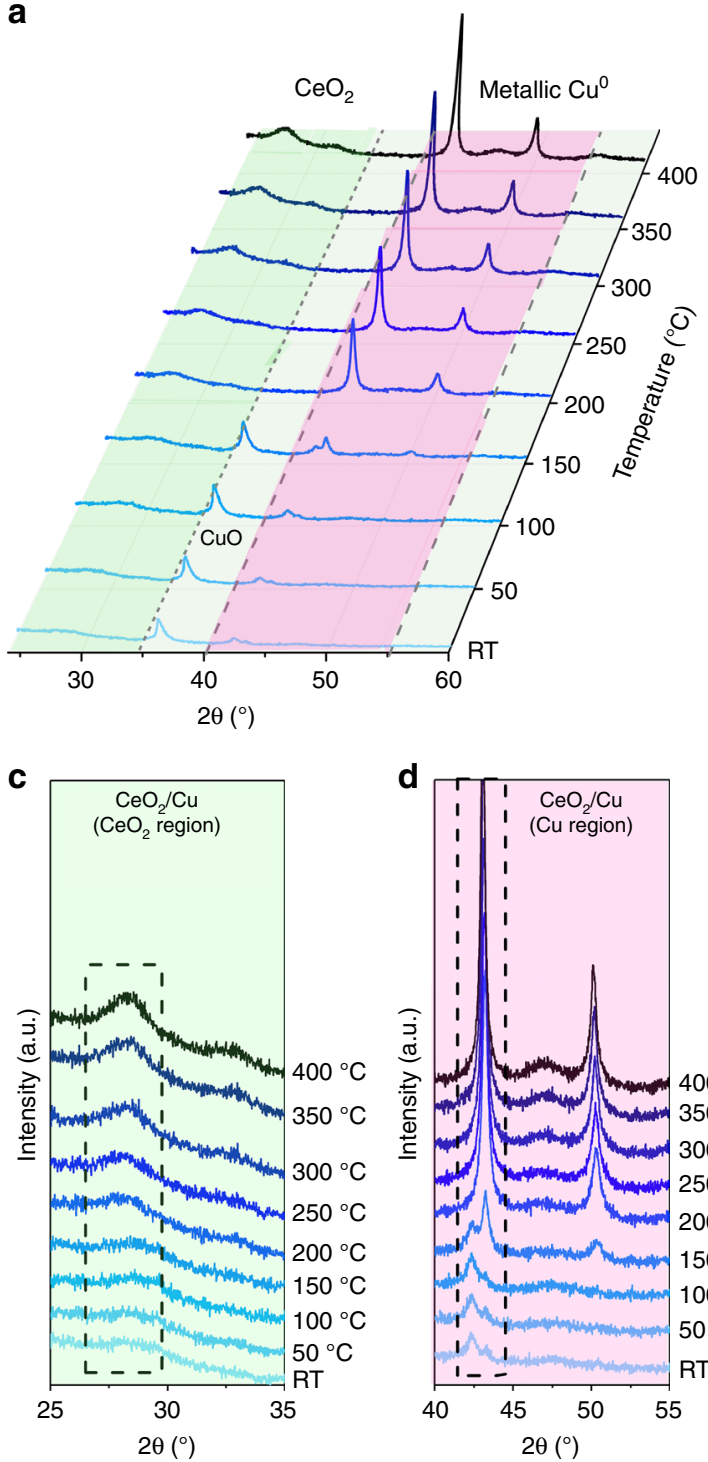

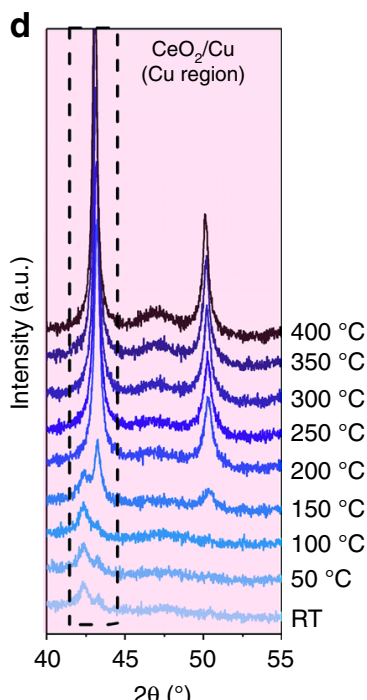

b
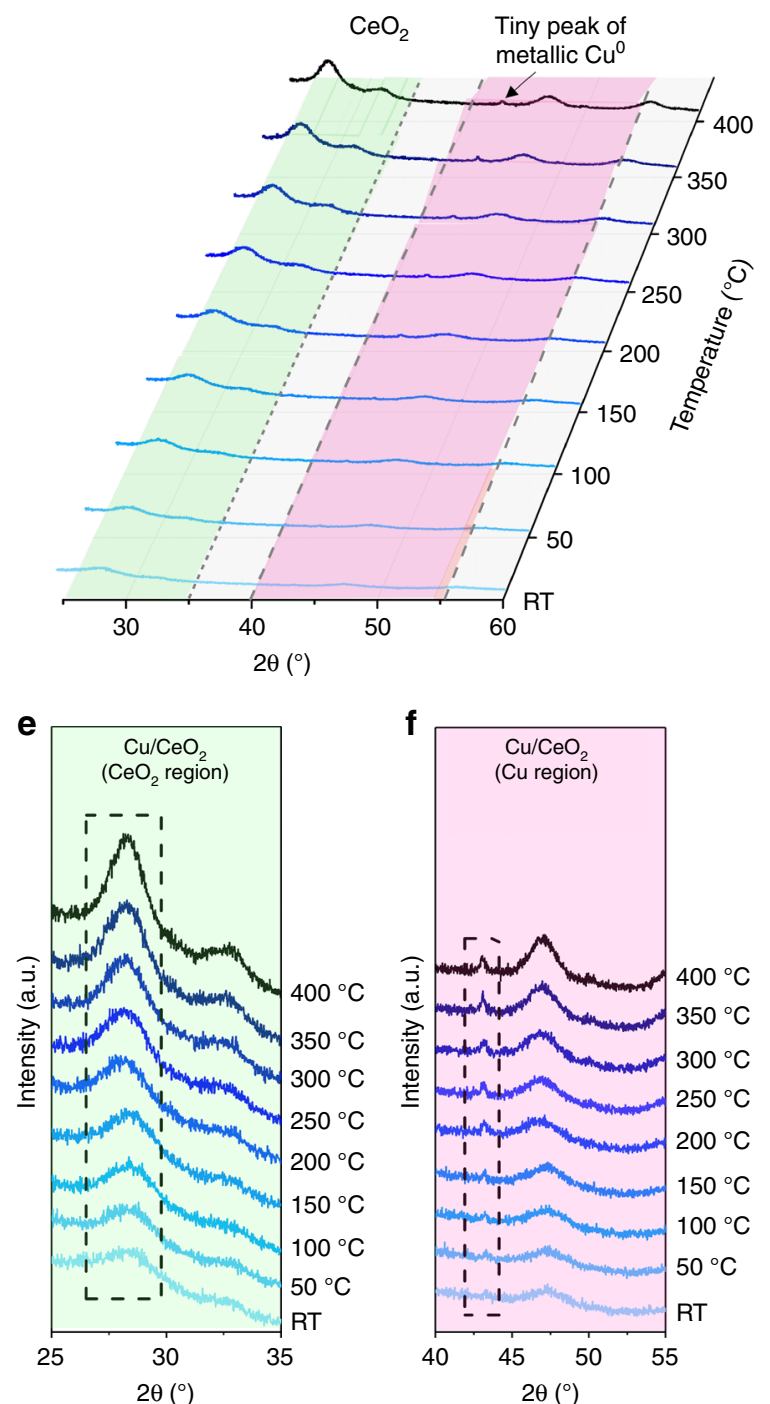

Fig. 3 Simulation of sintering via in situ XRD. a In situ XRD patterns under $5 \% \mathrm{H}_{2}$-Ar for inverse $\mathrm{CeO}_{2} / \mathrm{Cu}$ catalyst. b In situ XRD patterns under $5 \%$ H for normal $\mathrm{Cu} / \mathrm{CeO}_{2}$ catalyst. c Amplified $\mathrm{CeO}_{2}$ region of in situ XRD patterns for inverse $\mathrm{CeO}_{2} / \mathrm{Cu}$ catalyst. $\mathbf{d}$ Amplified $\mathrm{Cu}$ region of in situ XRD patterns for inverse $\mathrm{CeO}_{2} / \mathrm{Cu}$ catalyst. e Amplified $\mathrm{CeO}_{2}$ region of in situ XRD patterns for normal $\mathrm{Cu} / \mathrm{CeO}_{2}$ catalyst. $\mathbf{f}$ Amplified $\mathrm{Cu}$ region of in situ XRD patterns for normal $\mathrm{Cu} / \mathrm{CeO}_{2}$ catalyst

catalyst (Fig. 2c), which might due to the re-oxidation and dispersion of $\mathrm{Cu}$ under ex situ mode. Besides, the structural evolutions of $\mathrm{CeO}_{2}$ under reduction are given in Fig. 3c, e. The broad peaks suggested that $\mathrm{CeO}_{2}$ nanoparticles in inverse $\mathrm{CeO}_{2} / \mathrm{Cu}$ were maintained at very small size (2.1-2.9 nm, Supplementary Fig. 9), which was in accordance to the XRD data of used inverse catalyst $\left(2.6-2.7 \mathrm{~nm}\right.$, Table 1). Figure $3 \mathrm{e}$ shows that the $\mathrm{CeO}_{2}$ size of normal $\mathrm{Cu} / \mathrm{CeO}_{2}$ grew under $\mathrm{H}_{2}$ reduction $(2.8-5.3 \mathrm{~nm}$, Supplementary Fig. 9). Thus, compared to depositing $\mathrm{Cu}$ nanoparticles on $\mathrm{CeO}_{2}$ support, the dispersion of $\mathrm{CeO}_{2}$ on bulk $\mathrm{Cu}$ created more stable $\mathrm{CeO}_{2}-\mathrm{Cu}$ interfaces. This enrichment of stable interfaces for inverse $\mathrm{CeO}_{2} / \mathrm{Cu}$ catalyst resulted in tremendous promotion of WGS activity, corresponding well to former report, in which $\mathrm{Cu}-\mathrm{CeO}_{2}$ interface was suggested to have great importance in WGS model catalyst ${ }^{18}$.

WGS mechanism study. For WGS reaction, two catalytic mechanisms have been proposed, namely, redox mechanism and associative mechanism ${ }^{46-48}$. In the redox mechanism, $\mathrm{CO}$ reacts with surface oxygen of supports after adsorption, forming $\mathrm{CO}_{2}$ and oxygen vacancy. $\mathrm{H}_{2} \mathrm{O}$ dissociates at the vacancy and produces $\mathrm{H}_{2}$. In the associative mechanism, $\mathrm{CO}$ and $\mathrm{H}_{2} \mathrm{O}$ adsorb on the catalyst to form an intermediate, which decomposes to yield $\mathrm{CO}_{2}$ and $\mathrm{H}_{2}$. It has been proved that with associative mechanism, surface hydroxyl serves as the active species in $\mathrm{Au} / \mathrm{CeO}_{2}$ system $^{49,50}$. In this case, two $\mathrm{CO}$ molecules react with two surface hydroxyl groups to form $2 \mathrm{CO}_{2}$ molecules and $1 \mathrm{H}_{2}$ molecule:

$$
2 \mathrm{CO}+2 \mathrm{OH}=2 \mathrm{CO}_{2}+\mathrm{H}_{2}
$$

The amount of produced $\mathrm{CO}_{2}$ is supposed to be double of that of $\mathrm{H}_{2}$ in the outlet gas. Temperature-programmed surface reaction (TPSR) were carried out to check the reaction pathway. As shown in Fig. $4 \mathrm{~b}, \mathrm{CO}$ purging gave the ratio of generated $\mathrm{CO}_{2}$ and $\mathrm{H}_{2}$ as 2:1, corresponding very well to the above reaction. After $\mathrm{H}_{2} \mathrm{O}$ was introduced, no $\mathrm{H}_{2}$ signal was detected on $\mathrm{Cu} /$ $\mathrm{CeO}_{2}$, proving the pure associative mechanism for the normal $\mathrm{Cu} / \mathrm{CeO}_{2}$ catalyst. However, for the inverse $\mathrm{CeO}_{2} / \mathrm{Cu}$ catalyst (Fig. 4a), the ratio of generated $\mathrm{CO}_{2}$ and $\mathrm{H}_{2}$ was 3:1 after $\mathrm{CO}$ 

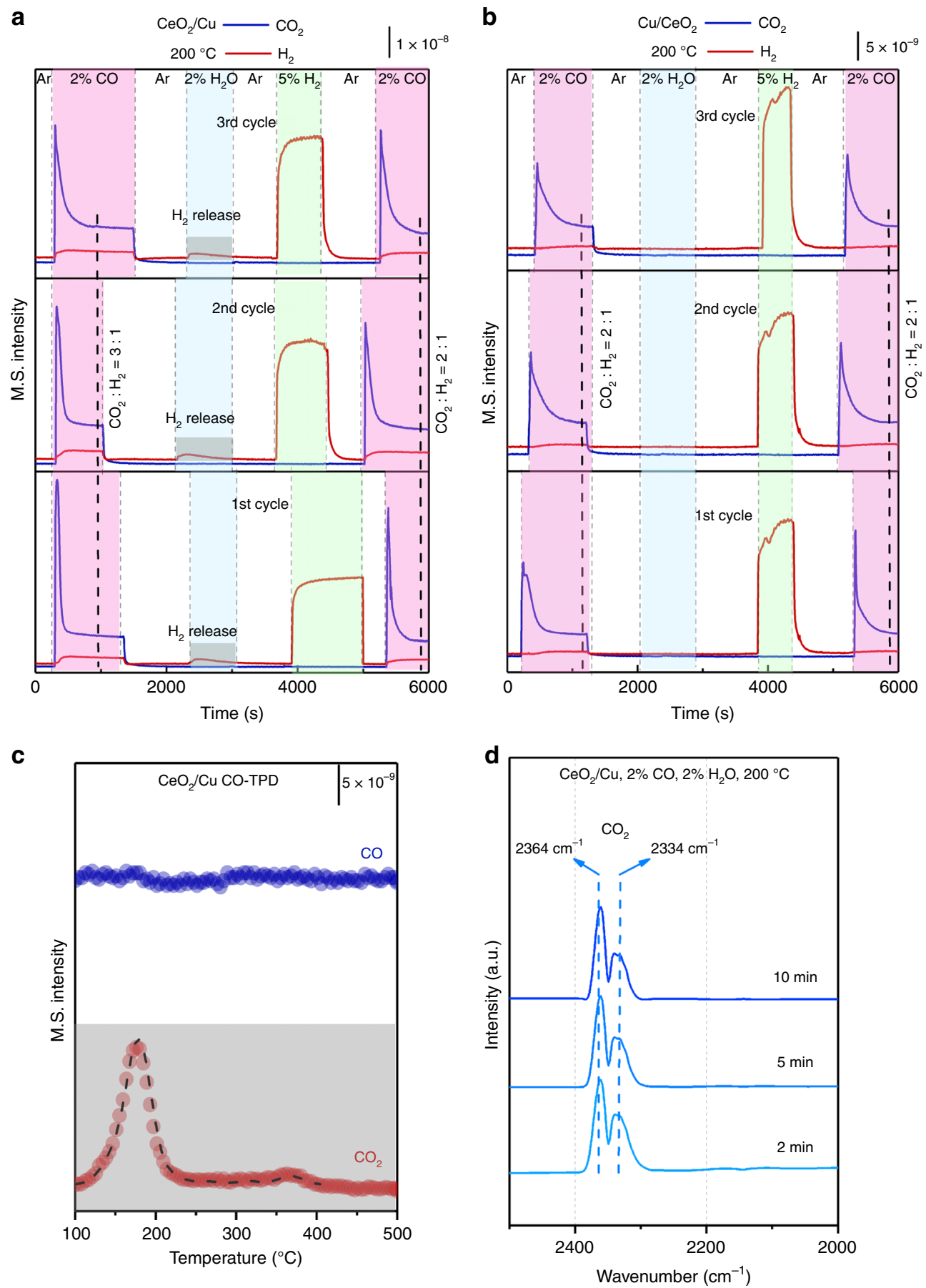

Fig. 4 WGS mechanism study of the inverse $\mathrm{CeO}_{2} / \mathrm{Cu}$ catalyst. a Temperature-programmed surface reaction (TPSR) on the inverse $\mathrm{CeO} / \mathrm{Cu}$ with consecutive switch of $\mathrm{CO}, \mathrm{H}_{2} \mathrm{O}$, and $\mathrm{H}_{2}$ at $200^{\circ} \mathrm{C}$. b TPSR on normal $\mathrm{Cu} / \mathrm{CeO}_{2}$ with consecutive switch of $\mathrm{CO}, \mathrm{H}_{2} \mathrm{O}$, and $\mathrm{H}_{2}$ at $200{ }^{\circ} \mathrm{C}$. c Temperatureprogrammed desorption of $\mathrm{CO}$ (CO-TPD) and $\mathbf{d}$ in situ diffused reflectance infrared Fourier transform spectroscopy (DRIFTS) results of the inverse $\mathrm{CeO}_{2} /$ $\mathrm{Cu}$ under the WGS conditions $\left(2 \% \mathrm{CO} / 2 \% \mathrm{H}_{2} \mathrm{O} / \mathrm{Ar}\right.$, at $\left.200{ }^{\circ} \mathrm{C}\right)$

introduction. This meant that besides the surface hydroxyls, active oxygen atoms created by the dissociation of $\mathrm{H}_{2} \mathrm{O}$ were also involved in the reaction. When $\mathrm{H}_{2} \mathrm{O}$ was injected, $\mathrm{H}_{2}$ formation could be observed immediately. These observations matched the features of redox mechanism, assuming that $\mathrm{H}_{2} \mathrm{O}$ dissociated on $\mathrm{CeO}_{2}$ oxygen vacancy to generate $\mathrm{H}_{2}$ and active surface oxygen atoms. After $\mathrm{H}_{2} \mathrm{O}$ injection, we removed the surface oxygen with $\mathrm{H}_{2}$ reduction and preserved the surface hydroxyls ${ }^{50}$, after which CO was purged into the system to conduct the TPSR test again. The subsequent $\mathrm{CO}$ treatment gave a $\mathrm{CO}_{2}: \mathrm{H}_{2}$ ratio of $2: 1$, showing the typical results of associative mechanism. The TPSR experiment was cycled three times in a row, and it gave very repeatable results for both catalysts. Thus, it turned out that both the redox and associative mechanism were present in the WGS reaction catalyzed by the inverse $\mathrm{CeO}_{2} / \mathrm{Cu}$ catalyst.

It has been generally believed that the redox mechanism occurs on metals ${ }^{46,47}$ and the associative mechanism dominates at the metal/oxide interface ${ }^{50,51}$. However, redox pathway has now been found on inverse $\mathrm{CeO}_{2} / \mathrm{Cu}$ catalyst. The improved redox properties of $\mathrm{CeO}_{2}$ nanoparticles on inverse $\mathrm{CeO}_{2} / \mathrm{Cu}$ played an important 
role. Temperature-programmed desorption of CO (CO-TPD) was applied to detect the $\mathrm{CO}$ sorption on the inverse catalyst. As illustrated in Fig. 4c, after $\mathrm{CO}$ pre-adsorption, $\mathrm{CO}_{2}$ was the only desorption species on $\mathrm{CeO}_{2} / \mathrm{Cu}$, showing easy transformation from $\mathrm{CO}$ to $\mathrm{CO}_{2}$. For better study over $\mathrm{CO}$ adsorption, diffuse reflectance infrared Fourier transform spectroscopy (DRIFTS) was introduced. As shown in Fig. 4d, the in situ DRIFTS of the inverse $\mathrm{CeO}_{2} / \mathrm{Cu}$ catalyst under WGS conditions exhibited $\mathrm{CO}_{2}$ signal $^{52}\left(2334,2364 \mathrm{~cm}^{-1}\right)$ at the beginning, which indicated the ongoing of WGS reaction. Meanwhile, no signal of $\mathrm{CO}$ was detected during the measurement, while normal $\mathrm{Cu} / \mathrm{CeO}_{2}$ gave $\mathrm{CO}-\mathrm{Cu}^{0}$ adsorption $\left(2094 \mathrm{~cm}^{-1}\right)^{53,54}$ (Supplementary Fig. 10b). Pure $\mathrm{Cu}$ showed no adsorption behavior under both WGS and CO modes, suggesting $\mathrm{CO}$ adsorption on bulk $\mathrm{Cu}$ was not favored (Supplementary Fig. 10c and d). Besides, the results of in situ DRIFTS for $\mathrm{CO}$ adsorption on the $\mathrm{CeO}_{2} / \mathrm{Cu}$ also only present $\mathrm{CO}_{2}$ signal, which showed that active surface species of the catalyst was reduced by CO (Supplementary Fig. 10a). Besides, we measured the reaction orders of $\mathrm{CO}$ and $\mathrm{H}_{2} \mathrm{O}$ for different catalysts. As shown in Supplementary Fig. 11, the $\mathrm{H}_{2} \mathrm{O}$ reaction order increased when $\mathrm{CeO}_{2}$ content was elevated, giving the catalyst stronger capability to consume $\mathrm{H}_{2} \mathrm{O}$. The $\mathrm{CO}$ reaction order on inverse $\mathrm{CeO}_{2} / \mathrm{Cu}$ was 0.75 , which suggested $\mathrm{CO}$ was comparatively insufficient during WGS reaction. All the above data demonstrated the easy transformation from $\mathrm{CO}$ to $\mathrm{CO}_{2}$ on inverse $\mathrm{CeO}_{2} / \mathrm{Cu}$, reflecting unique redox properties of the $\mathrm{CeO}_{2}$ nanoparticles. The surface oxygen of inverse $\mathrm{CeO}_{2} / \mathrm{Cu}$ was proved to be flexible under $\mathrm{CO}$, which facilitated the formation of defect sites.

Role of the surface defects in the catalysts. The formation of defect sites on inverse $\mathrm{CeO}_{2} / \mathrm{Cu}$ were evidenced by in situ Raman measurements, since ex situ Raman and XPS results did not show pronounced $\mathrm{Ce}^{3+}$ signals. As shown in Fig. 5a, the Raman spectra of the inverse $\mathrm{CeO}_{2} / \mathrm{Cu}$ after $\mathrm{H}_{2}$ activation gave a hump at $600 \mathrm{~cm}^{-1}$, which was ascribed to the intrinsic defects ${ }^{55,56}$. When $\mathrm{CO}$ was filled in, surface oxygen was removed, forming two characteristic peaks located at 546 and $456 \mathrm{~cm}^{-1}$, respectively. The peak centered at 546 $\mathrm{cm}^{-1}$ ( $D$ peak) resulted from defects where $\mathrm{Ce}^{4+}$ was replaced by $\mathrm{Ce}^{3+56}$, and the peak centered at $456 \mathrm{~cm}^{-1}$ was typical vibration mode $\left(F_{2 \mathrm{~g}}\right)$ of fluorite-type structure ${ }^{56,57}$. It is surprising that the Raman signals of the inverse $\mathrm{CeO}_{2} / \mathrm{Cu}$ showed that the defect $D$ peak was even more pronounced than $F_{2 g}$ peak. When $\mathrm{H}_{2} \mathrm{O}$ was introduced, the intensity of the $D$ peaks decreased apparently, which meant the $\mathrm{Ce}^{3+}$ defects were filled. The second cycle gave the same results. The introduction of $\mathrm{CO}$ induced the creation of surface defects through the reaction:

$$
\begin{gathered}
\mathrm{CO}+\mathrm{O} \rightarrow \mathrm{CO}_{2} \\
\mathrm{CO}+\mathrm{OH} \rightarrow \mathrm{CO}_{2}+1 / 2 \mathrm{H}_{2}
\end{gathered}
$$

For the normal $\mathrm{Cu} / \mathrm{CeO}_{2}$ catalyst (Fig. 5b), the intensity of $\mathrm{Ce}^{3+} D$ peaks was clearly weakened. The generation and elimination of defects with the $\mathrm{CO} / \mathrm{H}_{2} \mathrm{O}$ switch was also sluggish. In situ Raman under WGS conditions (Fig. 5c) showed consistent results. The inverse $\mathrm{CeO}_{2} / \mathrm{Cu}$ also gave more pronounced signal of surface defects under the WGS conditions, with $D / F_{2 \mathrm{~g}}$ integral ratio of 1.8. These results were totally different from those of pure $\mathrm{CeO}_{2}$ sample (Supplementary Fig. 12), which gave very strong $F_{2 \mathrm{~g}}$ peak and nearly no defect peak. The in situ Raman results have confirmed the enrichment of $\mathrm{Ce}^{3+}$ defect sites in inverse $\mathrm{CeO}_{2} /$ $\mathrm{Cu}$ under WGS conditions, which further proved the enhanced redox properties of $\mathrm{CeO}_{2}$ on inverse $\mathrm{CeO}_{2} / \mathrm{Cu}$.

For both catalysts, metallic $\mathrm{Cu}$ was the only phase detected under the WGS conditions. Supplementary Fig. 13 displayed the
TPSR results of inverse $\mathrm{CeO}_{2} / \mathrm{Cu}$ and normal $\mathrm{Cu} / \mathrm{CeO}_{2}$ catalysts. The WGS reaction began to occur at $\sim 100{ }^{\circ} \mathrm{C}$. After TPSR, the following $\mathrm{H}_{2}$-TPR measurement gave no $\mathrm{H}_{2}$ reduction peaks, which suggested $\mathrm{Cu}$ remained in fully metallic state during the WGS reaction. This finding was in accordance with the former work reported by Barrio et al. ${ }^{29}$ However, considering the very high WGS activity of the inverse $\mathrm{CeO}_{2} / \mathrm{Cu}$ catalyst, the active site was more likely to locate at $\mathrm{Cu}-\mathrm{CeO}_{2}$ interfaces rather than metallic $\mathrm{Cu}$.

\section{Discussion}

The mixed oxides of $\mathrm{Cu}-\mathrm{Zn}-\mathrm{Al}$ have been applied as industrial WGS catalysts for decades. Though lots of efforts have been made, few reports have found $\mathrm{Cu}$-based catalysts as effective as $\mathrm{Cu}-\mathrm{Zn}-\mathrm{Al}$, especially under industrial atmosphere. Herein, the inverse $\mathrm{CeO}_{2} / \mathrm{Cu}$ catalyst showed greatly promoted WGS activity, which was five times higher than that of normal $\mathrm{Cu} / \mathrm{CeO}_{2}$ catalyst. The WGS conversion of the inverse $\mathrm{CeO}_{2} / \mathrm{Cu}$ was very close to that of commercial $\mathrm{Cu}-\mathrm{Zn}-\mathrm{Al}$ under industrial WGS atmosphere, approaching the equilibrium maximum. The high WGS activity for the inverse $\mathrm{CeO}_{2} / \mathrm{Cu}$ catalyst originated from its unique structure, where bulk-nano interfaces were constructed. When $\mathrm{Cu}$ was loaded on $\mathrm{CeO}_{2}$, sintering was inevitable as the aggregation of $\mathrm{Cu}$ species lowered the surface energy. The dynamic elimination of $\mathrm{Cu}-\mathrm{CeO}_{2}$ interfaces caused rapid deactivation. Thus, for normal $\mathrm{Cu} / \mathrm{CeO}_{2}$ catalyst, though $\mathrm{Cu}-\mathrm{CeO}_{2}$ interfaces were created, the elimination due to structural change would take place even in $\mathrm{H}_{2}$ pre-treatment. This deactivation resulted in very low WGS $r$ in activity and stability tests (Fig. 1a, d). Considering its high $\mathrm{Cu}$ dispersion, the turnover frequency (TOF) of normal $\mathrm{Cu} / \mathrm{CeO}_{2}$ was calculated for single site on $\mathrm{Cu}-\mathrm{CeO}_{2}$ interface (see detail in Supplementary Methods). The derived TOF was $0.056 \mathrm{~s}^{-1}$, as shown in Table 1 .

Meanwhile, for inverse $\mathrm{CeO}_{2} / \mathrm{Cu}$ catalyst, bulk $\mathrm{Cu}$ formed steady structure under WGS conditions. Small $\mathrm{CeO}_{2}$ nanoparticles were dispersed on bulk $\mathrm{Cu}$ and were also very stable against sintering. The maximized and stabilized bulk-nano interfaces in the inverse $\mathrm{CeO}_{2} / \mathrm{Cu}$ catalyst gave significant WGS promotion. The high WGS activity resulted from the structural nature of the inverse $\mathrm{CeO}_{2} / \mathrm{Cu}$ catalyst, which lied in creation and preservation of stabilized bulk-nano interfaces. A theoretical model has been built to calculate TOF for the inverse $\mathrm{CeO}_{2} / \mathrm{Cu}$. A $3 \mathrm{~nm} \mathrm{CeO} \mathrm{Ce}_{2}$ nanoparticle with $231 \mathrm{Ce}$ atoms was loaded on metallic $\mathrm{Cu}$. As shown in Supplementary Fig. 14, $16 \mathrm{Ce}$ atoms were located at the periphery of $\mathrm{Cu}-\mathrm{CeO}_{2}$ interface. Based on this model, the TOF of the inverse $\mathrm{CeO}_{2} / \mathrm{Cu}$ catalyst for single site on $\mathrm{CeO}_{2}-\mathrm{Cu}$ interface was $0.058 \mathrm{~s}^{-1}$ (see detail in Supplementary Methods). The similar TOF of both catalysts proved that the $\mathrm{Cu}-\mathrm{CeO}_{2}$ and $\mathrm{CeO}_{2}-\mathrm{Cu}$ interfaces possessed the same intrinsic activities. As shown in Table 1, the amount of interface sites for inverse $\mathrm{CeO}_{2} / \mathrm{Cu}$ was four times higher than that for normal $\mathrm{Cu}$ / $\mathrm{CeO}_{2}$. The highly promoted WGS activity of inverse $\mathrm{CeO}_{2} / \mathrm{Cu}$ originated from the enrichment of interface sites. Besides, owing to the strong $\mathrm{Cu}-\mathrm{CeO}_{2}$ interaction, the redox properties of inverse $\mathrm{CeO}_{2} / \mathrm{Cu}$ catalyst were improved. The surface oxygen of inverse $\mathrm{CeO}_{2} / \mathrm{Cu}$ catalyst was proved to be flexible under $\mathrm{CO}$, leading to the formation of defects. $\mathrm{H}_{2} \mathrm{O}$ dissociated at the defects, promoting the WGS activity via a combination of both the associative mechanism and redox mechanism. The discussion of reactivity and mechanism was concluded in Fig. 6.

The pursuing of highly active and stable catalysts would never be out of date. A strategy to fabricate robust WGS catalyst was proposed, where the key was the construction of bulk-nano interfaces. By using aerosol-spray method, we developed the $\mathrm{CeO}_{2} / \mathrm{Cu}$ catalysts with inverse configuration. Small $\mathrm{CeO}_{2}$ 

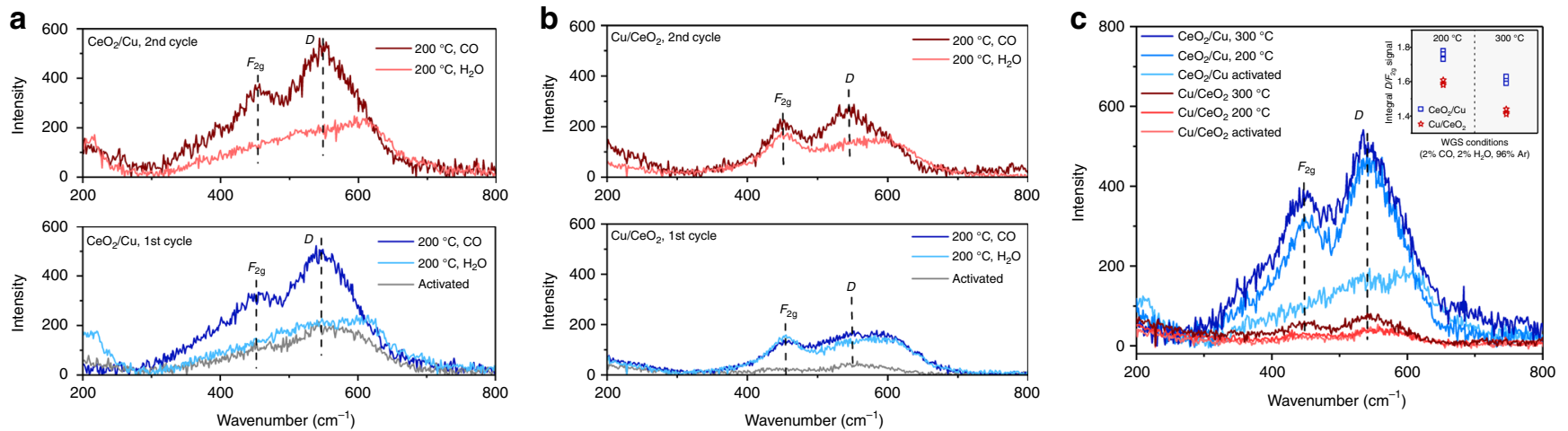

Fig. 5 Examination of defect sites in the catalysts. a In situ Raman spectra of the inverse $\mathrm{CeO}_{2} / \mathrm{Cu}$ with $\mathrm{CO} / \mathrm{H}_{2} \mathrm{O}$ switch under $200{ }^{\circ} \mathrm{C}$. b In situ Raman spectra of the normal $\mathrm{Cu} / \mathrm{CeO}_{2}$ with $\mathrm{CO} / \mathrm{H}_{2} \mathrm{O}$ switch under $200^{\circ} \mathrm{C}$. c In situ Raman under the WGS conditions for both catalysts, the inset figure gave $D / F_{2 g}$ integral ratio at different temperatures

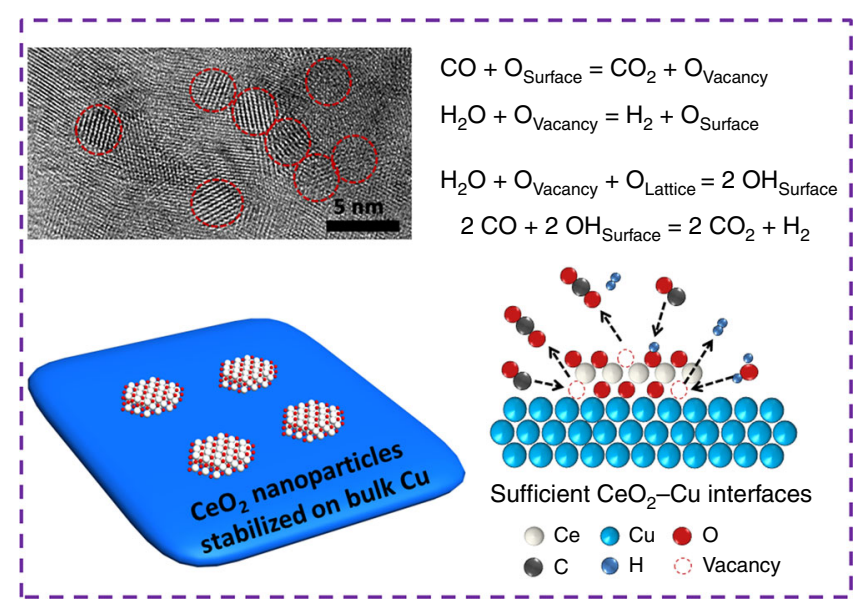

Fig. 6 Role of inverse $\mathrm{CeO}_{2} / \mathrm{Cu}$ in catalyzing the WGS reaction. Role of the $\mathrm{CeO}_{2}-\mathrm{Cu}$ interfaces in catalyzing the WGS reaction on inverse $\mathrm{CeO}_{2} / \mathrm{Cu}$ catalyst

nanoparticles $(2-3 \mathrm{~nm})$ were stabilized on bulk $\mathrm{Cu}$, forming stable $\mathrm{CeO}_{2}-\mathrm{Cu}$ interfaces under reaction conditions. The enrichment and preservation of such interfaces resulted in significant promotion in activity. The inverse $\mathrm{CeO}_{2} / \mathrm{Cu}$ catalyst exhibited great WGS activity, which was at least five times higher than other reported $\mathrm{Cu}$ catalysts. The improved redox properties of the inverse $\mathrm{CeO}_{2} / \mathrm{Cu}$ catalyst facilitated the $\mathrm{H}_{2} \mathrm{O}$ dissociation and $\mathrm{CO}$ oxidation, boosting WGS activity via the combination of associative and redox mechanism. Catalyst with sufficient bulk-nano interfaces has now been proved to give excellent WGS performances under realistic conditions, and show great potentials in practical applications and other catalytic systems.

\section{Methods}

Catalyst preparation. In a typical synthesis of $\mathrm{Cu}_{a} \mathrm{Ce}_{b} \mathrm{O}_{x}, 4 \mathrm{mmol}$ of metal nitrates (99\%, Tianjin Kermal Factory) were added to $60 \mathrm{ml}$ of absolute ethanol (99\%, Tianjin Fuyu Fine Chemical Reagent Factory). This mixture was stirred for $10 \mathrm{~min}$ and then put into a ultrasonic humidifier $(30 \mathrm{~W}, 1.5 \mathrm{MHz})$. Industrial $\mathrm{N}_{2}$ served as the carrier gas to bring the spray generated through sonication into the tube furnace (pre-heated to $400{ }^{\circ} \mathrm{C}$ ). The mist drop evaporated and the precursor underwent decomposition and self-assembly. The metal oxides products were spherical nanoparticles, which were collected on a piece of filter paper and dried overnight at $60^{\circ} \mathrm{C}$. Then, the obtained powder was calcined in air for $4 \mathrm{~h}\left({ }^{\circ} \mathrm{C} \mathrm{min}^{-1}\right.$ of ramping rate). The obtained catalysts were nominated as $\mathrm{Cu}_{a} \mathrm{Ce}_{b} \mathrm{O}_{x}$, of which $a$ and $b$ referred to the molar ratio of corresponding element, respectively. Commercial $\mathrm{Cu}-\mathrm{Zn}-\mathrm{Al}$ catalyst (37 wt $\% \mathrm{CuO}, 52 \mathrm{wt} \% \mathrm{ZnO}, 11 \mathrm{wt} \% \mathrm{Al}_{2} \mathrm{O}_{3}$, determined by $\mathrm{EDS}$ ) was bought from Sichuan Shutai Chemical Engineering Company.
Transmission electron microscope (TEM). All images of TEM were taken on a JEOL JEM-2100F microscope, of which the acceleration voltage was $200 \mathrm{kV}$. The images of HR-TEM were obtained by using a Philips Tecnai F20 instrument with the acceleration voltage of $200 \mathrm{kV}$. The element mapping results and EDS analysis were acquired from the same machine under STEM mode.

X-ray diffraction (XRD). For the XRD data, all experiments were performed on a PANalytical B.V. X'pert3 powder diffractometer with $\mathrm{CuK}_{\alpha}$ radiation $(\lambda=0.15418$ $\mathrm{nm}$ ). Accelerating voltage and current of $40 \mathrm{kV}$ and $40 \mathrm{~mA}$ were applied for ex situ and in situ modes. Ex situ XRD patterns were obtained by using a PIXcell ${ }^{\mathrm{D}}$ detector in the $2 \theta$ range of $20-80^{\circ}$. For the in situ XRD experiments, an Anton Paar XRK900 in situ chamber was applied. The XRD data were measured from 50 to $400{ }^{\circ} \mathrm{C}$ in $5 \% \mathrm{H}_{2} /$ Ar mixture $\left(30 \mathrm{~cm}^{3} \mathrm{~min}^{-1}\right)$.

X-ray photoelectron spectroscopy (XPS). The XPS measurements were performed on an Axis Ultra XPS spectrometer from Kratos, Japan. The operation was under $225 \mathrm{~W}$ of accelerating voltage and $\mathrm{Al} \mathrm{K}_{\alpha}$ radiation. The $\mathrm{C} 1 \mathrm{~s}$ line located at $284.8 \mathrm{eV}$ was used to calibrate each spectra for accurate binding energies.

Raman spectroscopy. Ex situ and in situ Raman spectra were obtained by excitation of the catalysts at $633 \mathrm{~nm}$ laser, using a LabRAM HR800 Raman spectrometer (Horiba Jobin Yvon) with the range from 200 to $800 \mathrm{~cm}^{-1}$ in a spectral resolution of $2 \mathrm{~cm}^{-1}$

Temperature-programmed surface reaction (TPSR). An online mass spectrometer (Ametek LC-D200M) was used to analyze the outlet gases for TPSR, as well as CO-TPD. $100 \mathrm{mg}$ of each sample were treated with $5 \% \mathrm{H}_{2} / \mathrm{Ar}\left(30 \mathrm{~cm}^{3} \mathrm{~min}^{-1}\right)$ for $30 \mathrm{~min}$ at $300^{\circ} \mathrm{C}$ before test. The sample was then flushed under pure He for $1 \mathrm{~h}$. For CO-TPD, the samples were purged with $5 \% \mathrm{CO} / \mathrm{Ar}\left(30 \mathrm{~cm}^{3} \mathrm{~min}^{-1}\right)$ for $0.5 \mathrm{~h}$, and then flushed under pure $\mathrm{He}$ for another $1 \mathrm{~h}$ at room temperature. Afterwards, the samples were heated from room temperature to $500^{\circ} \mathrm{C}$ under He flow. For TPSR, the catalysts were heated from 120 to $400{ }^{\circ} \mathrm{C}$ under $2 \% \mathrm{H}_{2} \mathrm{O}, 2 \%$ $\mathrm{CO} / \mathrm{Ar}$ gas flow $\left(30 \mathrm{~cm}^{3} \mathrm{~min}^{-1}\right)$. For the examination of reaction mechanisms, the samples went through WGS reaction for $1 \mathrm{~h}$ at $200^{\circ} \mathrm{C}$ after $\mathrm{H}_{2}$ reduction. The catalysts were then purged by $\mathrm{Ar}$ at $200^{\circ} \mathrm{C}$, followed by the switch of $2 \% \mathrm{CO} / \mathrm{Ar}$, pure $\mathrm{Ar}, 2 \% \mathrm{H}_{2} \mathrm{O} / \mathrm{Ar}$, pure $\mathrm{Ar}, 5 \% \mathrm{H}_{2} / \mathrm{Ar}$, pure $\mathrm{Ar}$, and $2 \% \mathrm{CO} / \mathrm{Ar}$ to collect the mass spectrometer signal. The heating rate for all tests was set as $10^{\circ} \mathrm{C} \mathrm{min}-1$.

Catalytic tests and kinetics measurement. A fixed-bed reactor with diameter of $1 \mathrm{~cm}$ was used for the WGS reaction tests. In order to give accurate results, a thermocouple connected with a PID temperature controller was mounted on top of the catalyst bed. The catalyst powder $(100 \mathrm{mg})$ was loaded and reduced with $5 \%$ $\mathrm{H}_{2} / \mathrm{Ar}$ mixture for $0.5 \mathrm{~h}$ at $300{ }^{\circ} \mathrm{C}$. The reaction gas contained $2 \% \mathrm{CO}$ and $10 \%$ $\mathrm{H}_{2} \mathrm{O}$, balanced with $\mathrm{N}_{2}$. The total gas hourly space velocity (GHSV) was 42,000 $\mathrm{cm}^{3} \mathrm{~g}^{-1} \mathrm{~h}^{-1}$. In order to prevent water condensation, all pipes of the reactor were binded with heating belts. The activity results of catalysts were measured from 150 to $400^{\circ} \mathrm{C}$ as $50^{\circ} \mathrm{C}$ per step. Each catalyst was tested repeatedly to rule out the uncertainty. A Gasboard 3500 IR spectroscopy (WuhanSifang Company, China) was used to analyze all the outlet gases online. For the stability tests, the $\mathrm{CO}$ conversion data of the catalysts were continuously recorded under $250^{\circ} \mathrm{C}$ for $50 \mathrm{~h}$. The mass of the catalysts and the flow rate of reaction gas were tuned to keep the CO conversion under $15 \%$. The WGS activity was measured by means of CO conversion, which was defined as the following formula:

$$
X_{\mathrm{CO}}(\%)=\left(n_{\mathrm{CO}}^{\text {in }}-n_{\mathrm{CO}}^{\text {out }}\right) / n_{\mathrm{CO}}^{\text {in }} \times 100 \%
$$


For the kinetic tests, $20 \mathrm{mg}$ of catalysts were pre-reduced with $5 \% \mathrm{H}_{2} / \mathrm{Ar}$ mixture. The apparent activation energy $\left(E_{\mathrm{a}}\right)$ of each catalyst for WGS reaction was obtained by keeping $10 \%$ equal $\mathrm{CO}$ conversion with the regulation of reaction temperature, catalysts mass, and stream flow rate. The calculation of reaction rate $(r)$ for WGS followed the equation:

$$
r=F \times \mathrm{CO}_{\text {converted }} / W
$$

where $F$ is the total flow rate of the reaction stream $\left(\mathrm{mol} \mathrm{s}^{-1}\right) . r$ is the WGS reaction rate by means of $\mathrm{CO}\left(\mathrm{mol} \mathrm{g}^{-1} \mathrm{~s}^{-1}\right)$. $\mathrm{CO}_{\text {converted }}$ is the concentration of converted CO on the IR spectroscopy and $W$ is the mass of the catalyst (g).

The reaction orders of $\mathrm{CO}$ and $\mathrm{H}_{2} \mathrm{O}$ for the catalysts were measured under $250^{\circ} \mathrm{C}$. The WGS activity was recorded while the concentration of $\mathrm{CO}$ or $\mathrm{H}_{2} \mathrm{O}$ in the reaction gas was varied on purpose.

\section{Data availability}

The main data supporting the findings of this study are available within the article and its Supplementary information. Extra data are available from the corresponding author upon request.

Received: 15 February 2019 Accepted: 8 July 2019

Published online: 02 August 2019

\section{References}

1. Kowalczyk, Z. et al. Effect of potassium on the kinetics of ammonia synthesis and decomposition over fused iron catalyst at atmospheric pressure. J. Catal. 169, 407-414 (1997).

2. Koryabkina, N. A. et al. Determination of kinetic parameters for the water-gas-shift reaction on copper catalysts under realistic conditions for fuel cell applications. J. Catal. 217, 233-239 (2003).

3. Qiao, B. et al. Single-atom catalysis of $\mathrm{CO}$ oxidation using Pt1/FeOx. Nat. Chem. 3, 634-641 (2011).

4. Yang, M. et al. Catalytically active $\mathrm{Au}-\mathrm{O}(\mathrm{OH}) \mathrm{x}$-species stabilized by alkali ions on zeolites and mesoporous oxides. Science 346, 1498-1501 (2014).

5. Guo, L. W. et al. Contributions of distinct gold species to catalytic reactivity for carbon monoxide oxidation. Nat. Commun. 7, 13481 (2016).

6. Yao, S. et al. Atomic-layered Au clusters on $\alpha-\mathrm{MoC}$ as catalysts for the lowtemperature water-gas shift reaction. Science 357, 389-393 (2017).

7. Liu, L. \& Corma, A. Metal catalysts for heterogeneous catalysis: from single atoms to nanoclusters and nanoparticles. Chem. Rev. 118, 4981-5079 (2018).

8. Campbell, C. T. et al. The effect of size-dependent nanoparticle energetics on catalyst sintering. Science 298, 811-814 (2002).

9. Carter, J. H. et al. Activation and deactivation of gold/ceria-zirconia in the low-temperature water-gas-shift reaction. Angew. Chem. Int. Ed. 56, 16037-16041 (2017).

10. Dai, Y., Lu, P., Cao, Z., Campbell, C. T. \& Xia, Y. The physical chemistry and materials science behind sinter-resistant catalysts. Chem. Soc. Rev. 47, 4314-4331 (2018).

11. Ratnasamy, T. et al. Water gas shift catalysis. Catal. Rev. Sci. Eng. 51, 325-440 (2009).

12. Gawande, M. B. et al. $\mathrm{Cu}$ and $\mathrm{Cu}$-based nanoparticles: synthesis and applications in catalysis. Chem. Rev. 116, 3722-3811 (2016).

13. Campbell, C. T. \& Daube, K. A. A surface science investigation of the water-gas-shift reaction on $\mathrm{Cu}$ (111). J. Catal. 104, 109-119 (1987).

14. Nakamura, J., Campbell, J. M. \& Campbell, C. T. Kinetics and mechanism of the water-gas shift reaction catalysed by the clean and Cs-promoted $\mathrm{Cu}(110)$ surface: a comparison with $\mathrm{Cu}$ (111). J. Chem. Soc. Faraday Trans. 86, 2725-2734 (1990).

15. Li, Y., Fu, Q. \& Flytzani-Stephanopoulos, M. Low-temperature water-gas shift reaction over $\mathrm{Cu}-$ and $\mathrm{Ni}-\mathrm{loaded}$ cerium oxide catalysts. Appl. Catal. B 27, 179-191 (2000).

16. Qi, X. \& Flytzani-Stephanopoulos, M. Activity and stability of $\mathrm{Cu}-\mathrm{CeO} 2$ catalysts in high-temperature water-gas shift for fuel-cell applications. Ind. Eng. Chem. Res. 43, 3055-3062 (2004).

17. Zerva, C. \& Philippopoulos, C. J. Ceria catalysts for water gas shift reaction: influence of preparation method on their activity. Appl. Catal. B 67, 105-112 (2006).

18. Mudiyanselage, $\mathrm{K}$. et al. Importance of the metal-oxide interface in catalysis: in situ studies of the water-gas shift reaction by ambient-pressure $\mathrm{x}$-ray photoelectron spectroscopy. Angew. Chem. Int. Ed. 52, 5101-5105 (2013).

19. Aranifard, S., Ammal, S. C. \& Heyden, A. On the importance of metal-oxide interface sites for the water-gas shift reaction over $\mathrm{Pt} / \mathrm{CeO} 2$ catalysts. J. Catal. 309, 314-324 (2014).

20. Xu, M. et al. Insights into interfacial synergistic catalysis over Ni@TiO2-x catalyst toward water-gas shift reaction. J. Am. Chem. Soc. 140, 11241-11251 (2018).
21. Rodriguez, J. A. \& Hrbek, J. Inverse oxide/metal catalysts: a versatile approach for activity tests and mechanistic studies. Surf. Sci. 604, 241-244 (2010).

22. Senanayake, S. D. et al. Unique properties of ceria nanoparticles supported on metals: novel inverse ceria/copper catalysts for $\mathrm{CO}$ oxidation and the watergas shift reaction. Acc. Chem. Res. 46, 1702-1711 (2013).

23. Rodriguez, J. A. et al. Inverse oxide/metal catalysts in fundamental studies and practical applications: a perspective of recent developments. J. Phys. Chem. Lett. 7, 2627-2639 (2016).

24. Rodriguez, J. A., Ma, S., Liu, P., Hrbek, J., Evans, J. \& Pérez, M. Activity of $\mathrm{CeOx}$ and $\mathrm{TiOx}$ nanoparticles grown on $\mathrm{Au}(111)$ in the water-gas shift reaction. Science 318, 1757-1760 (2007)

25. Shi, J. et al. Nanoporous gold-supported ceria for the water-gas shift reaction: UHV inspired design for applied catalysis. Catal. J. Phy. Chem. C 118, 29270-29277 (2014)

26. Shi, J. et al. A versatile sol-gel coating for mixed oxides on nanoporous gold and their application in the water gas shift reaction. Catal. Sci. Technol. 6 , 5311-5319 (2016)

27. Shi, J. et al. Steam reforming of methanol over oxide decorated nanoporous gold catalysts: a combined in situ FTIR and flow reactor study. Phys. Chem. Chem. Phys. 19, 8880-8888 (2017).

28. Rodriguez, J. A. et al. Water-gas shift reaction on a highly active inverse $\mathrm{CeOx} /$ $\mathrm{Cu}$ (111) catalyst: unique role of ceria nanoparticles. Angew. Chem. Int. Ed. 121, 8191-8194 (2009).

29. Barrio, L. et al. Unraveling the active site in copper-ceria system for the watergas shift reaction: in situ characterization of an inverse powder $\mathrm{CeO} 2-\mathrm{x} /$ CuO-Cu catalyst. J. Phy. Chem. C 114, 3580-3587 (2010).

30. Lu., Y. et al. Aerosol-assisted self-assembly of mesostructured spherical nanoparticles. Nature 398, 223-226 (1999).

31. Jin, Z., Xiao, M., Bao, Z., Wang, P. \& Wang, J. A general approach to mesoporous metal oxide microspheres loaded with noble metal nanoparticles. Angew. Chem. Int. Ed. 51, 6406-6410 (2012).

32. Yan, H. et al. Promoted multimetal oxide catalysts for the generation of hydrogen via ammonia decomposition. J. Phy. Chem. C 120, 7685-7696 (2016).

33. Gawade, P., Mirkelamoglu, B. \& Ozkan, U. S. The role of support morphology and impregnation medium on the water gas shift activity of ceria-supported copper catalysts. J. Phy. Chem. C 114, 18173-18181 (2010).

34. Si, R., Zhang, L., Chan, S. W. \& Flytzani-Stephanopoulos, M. Structure sensitivity of the low-temperature water-gas shift reaction on $\mathrm{Cu}-\mathrm{CeO} 2$ catalysts. Catal. Today 180, 68-80 (2012).

35. Saw, E. T. et al. Bimetallic Ni-Cu catalyst support on $\mathrm{CeO} 2$ for hightemperature water-gas shift reaction: methane suppression via enhanced $\mathrm{CO}$ adsorption. J. Catal. 314, 32-46 (2014).

36. Miao, D., Goldbach, A. \& Xu, H. Platinum/apatite water-gas shift catalysts. ACS Catal. 6, 775-783 (2016)

37. Fu, Q., Saltsburg, H. \& Flytzani-Stephanopoulos, M. Active nonmetallic Au and Pt species on ceria-based water-gas shift catalysts. Science 301, 935-938 (2003).

38. Yan, H., Qin, X. T., Yin, Y., Teng, Y. F., Jin, Z. \& Jia, C. J. Promoted $\mathrm{Cu}-\mathrm{Fe} 3 \mathrm{O} 4$ catalysts for low-temperature water gas shift reaction: optimization of Cu content. Appl. Catal. B 226, 182-193 (2018).

39. Yang, F. et al. $\mathrm{CeO} 2 \leftrightarrow \mathrm{CuOx}$ interactions and the controlled assembly of $\mathrm{CeO} 2$ (111) and $\mathrm{CeO} 2(100)$ nanoparticles on an oxidized $\mathrm{Cu}$ (111) substrate. J. Phys. Chem. C 115, 23062-23066 (2011).

40. Konsolakis, M. The role of copper-ceria interactions in catalysis science: recent theoretical and experimental advances. Appl. Catal. B 198, 49-66 (2016).

41. Wang, X. et al. Sacrificial adsorbate strategy achieved strong metal-support interaction of stable Cu nanocatalysts. ACS Appl. Energy Mater. 1, 1408-1414 (2018).

42. Fu, J., Ji, W., Shen, Z. \& Tang, S. Preparation and characterization of $\mathrm{CuO}$ nanocrystals. J. Solid State Chem. 147, 516-519 (1999).

43. Reina, T. R. et al. The role of $\mathrm{Au}, \mathrm{Cu} \& \mathrm{CeO} 2$ and their interactions for an enhanced WGS performance. Appl. Catal. B 187, 98-107 (2016).

44. Wang, W. et al. Crystal plane effect of ceria on supported copper oxide cluster catalyst for $\mathrm{CO}$ oxidation: importance of metal-support interaction. ACS Catal. 7, 1313-1329 (2017).

45. Yahiro, H. et al. Study on the supported Cu-based catalysts for the lowtemperature water-gas shift reaction. Catal. Today 126, 436-440 (2007).

46. Gokhale, A. A., Dumesic, J. A. \& Mavrikakis, M. On the mechanism of lowtemperature water gas shift reaction on copper. J. Am. Chem. Soc. 130, $1402-1414$ (2008).

47. Lin, C. H., Chen, C. L. \& Wang, J. H. Mechanistic studies of water-gasshift reaction on transition metals. J. Phy. Chem. C 115, 18582-18588 (2011).

48. Kalamaras, C. M., Americanou, S. \& Efstathiou, A. M. "Redox" vs. "associative formate with $-\mathrm{OH}$ group regeneration" WGS reaction mechanism on $\mathrm{Pt}$ / CeO2: effect of platinum particle size. J. Catal. 279, 287-300 (2011). 
49. Zhai, Y. et al. Alkali-stabilized Pt-OHx species catalyze low-temperature water-gas shift reactions. Science 329, 1633-1636 (2010).

50. Fu, X. et al. Direct identification of active surface species for the water-gas shift reaction on a gold-ceria catalyst. J. Am. Chem. Soc. 141, 4613-4623 (2019).

51. Aranifard, S., Ammal, S. C. \& Heyden, A. On the importance of metal-oxide interface sites for the water-gas shift reaction over $\mathrm{Pt} / \mathrm{CeO} 2$ catalysts. J. Catal. 309, 314-324 (2014).

52. Chen, C. S. et al. Active sites on $\mathrm{Cu}-\mathrm{SiO} 2$ prepared using the atomic layer technique for a low-temperature water-gas shift reaction. J. Catal. 263, 155-166 (2009).

53. Chen, C. S., Lai, T. W. \& Chen, C. C. Effect of active sites for a wate-gas shift reaction on $\mathrm{Cu}$ nanoparticles. J. Catal. 273, 18-28 (2010).

54. Yao, S. Y. et al. Morphological effect of the nanostructured ceria support on the activity and stability of $\mathrm{CuO} / \mathrm{CeO} 2$ catalysts for water-gas shift reaction. Phys. Chem. Chem. Phys. 16, 17183-19195 (2014).

55. Mcbride, J. R. et al. Raman and $\mathrm{x}$-ray studies of $\mathrm{Ce} 1-\mathrm{xRExO} 2-\mathrm{y}$, where RE=La, Pr, Nd, Eu, Gd, and Tb. J. Appl. Phys. 76, 2435-2441 (1994).

56. Wu, Z. et al. Probing defect sites on $\mathrm{CeO} 2$ nanocrystals with well-defined surface planes by Raman spectroscopy and O2 adsorption. Langmuir 26, 16595-16606 (2010).

57. Guo, M. et al. UV and visible Raman studies of oxygen vacancies in rareearth-doped ceria. Langmuir 27, 3872-3877 (2011)

\section{Acknowledgements}

This work is financially supported from the Excellent Young Scientists Fund from National Science Foundation of China (NSFC, grant nos. 21622106), other projects from the NSFC (grant nos. 21501109, 21771117, and 21805167), the Taishan Scholar Project of Shandong Province of China, the Outstanding Young Scholar Fund (grant no. JQ201703), and the Doctoral Fund (grant no. ZR2018BB010) from Science Foundation of Shandong Province of China and the Foundation of State Key Laboratory of Coal Conversion (grant no. J17-18-902). We thank the Center of Structural Characterizations and Property Measurements at Shandong University for the help on sample characterizations.

\section{Author contributions}

C.-J.J. supervised the work; H.Y., Z.J. and C.-J.J. had the idea for and designed the experiments, analyzed the results, and wrote the manuscript; H.Y., C.Y. and W.-P.S. performed the catalyst preparation and catalytic tests; H.Y. and L.-H.C. performed the TPSR, TPD, and kinetic experiments; H.Y. and W.-W.W. performed the ex situ and in situ XRD, Raman, and DRIFTS measurements.

\section{Additional information}

Supplementary Information accompanies this paper at https://doi.org/10.1038/s41467019-11407-2.

Competing interests: The authors declare no competing interests.

Reprints and permission information is available online at http://npg.nature.com/ reprintsandpermissions/

Peer review information: Nature Communications thanks the anonymous reviewers for their contribution to the peer review of this work. Peer reviewer reports are available.

Publisher's note: Springer Nature remains neutral with regard to jurisdictional claims in published maps and institutional affiliations.

\begin{abstract}
(c) (1)
Open Access This article is licensed under a Creative Commons Attribution 4.0 International License, which permits use, sharing, adaptation, distribution and reproduction in any medium or format, as long as you give appropriate credit to the original author(s) and the source, provide a link to the Creative Commons license, and indicate if changes were made. The images or other third party material in this article are included in the article's Creative Commons license, unless indicated otherwise in a credit line to the material. If material is not included in the article's Creative Commons license and your intended use is not permitted by statutory regulation or exceeds the permitted use, you will need to obtain permission directly from the copyright holder. To view a copy of this license, visit http://creativecommons.org/licenses/by/4.0/.
\end{abstract}

(c) The Author(s) 2019 